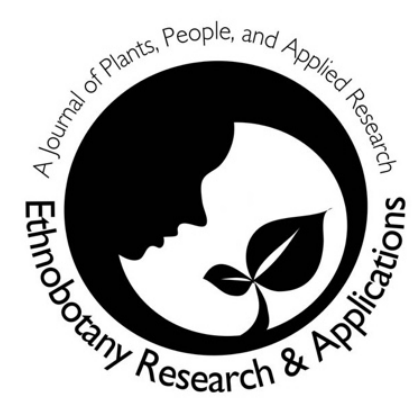

\title{
Treatment of Urolithiasis: Ethnobotanical Study of Plants Used by the Population Bordering the Forest of Izarène
}

\author{
Hicham Orch, Ouafae Benkhnigue, Mohamed Fadli, \\ Lahcen Zidane and Allal Douira
}

\section{Research}

\begin{abstract}
Background: In order to valorize and safeguard ancestral knowledge of medicinal plants used in traditional pharmacopoeia in the treatment of urolithiasis, an ethnobotanical study was carried out near the riverine population of the forest of Izarène.
\end{abstract}

Methods: Using 480 questionnaire cards, ethnobotanical field surveys were conducted during three campaigns (2013-2016). The different survey environments were determined using probabilistic stratified sampling techniques. The data were organized and analyzed by descriptive statistics. Ethnobotanical data were analyzed through the calculation of different quantitative indices, such as: Relative Frequency of Citation (RFC), Family Importance Value index (FIV) and Use value of the Plant Part (PPV).

Results: The results showed 53 useful plant species, belonging to 24 botanical families, which have been reported in the treatment of renal lithiasis. The Lamiaceae family was the most represented (10 species, FIV $=0.043)$. The highest Relative Citation Frequency (RFC) (0.173) was recorded for Herniaria hirsutas. The results obtained also showed that leaves are the most used part (PPV $=0.216$ ). The decoction is the dominant method of preparation and the administration is mainly oral.

Conclusions: The results obtained could constitute a database in the perspective of phytochemical, pharmacological and implementation experiments of innovative initiatives that could lead in the future to the manufacture of traditional drugs used in the treatment of renal lithiasis.
Keywords: Medicinal plants, forest of Izarène, ethnobotanical surveys, renal lithiasis.

\section{Correspondence}

Hicham Orch ${ }^{1 *}$, Ouafae Benkhnigue ${ }^{1}$, Mohamed Fadli $^{1}$, Lahcen Zidane ${ }^{1}$, Allal Douira ${ }^{2}$

${ }^{1}$ Laboratory of Natural Resources and Biodiversity, Department of Biology, Faculty of Sciences, Ibn Tofail University, BP 133, 14000, Kenitra, Morocco. 2Laboratory of Botany, Biotechnology and Plant Protection, Department of Biology, Faculty of Sciences, Ibn Tofail University, BP 133, 14000, Kenitra, Morocco.

*Corresponding Author: orch3108@gmail.com

Ethnobotany Research \& Applications 19:33 (2020)

\section{Resume}

Contexte: Pour valoriser et sauvegarder les connaissances ancestrales sur les plantes médicinales utilisées en pharmacopée traditionnelle dans le traitement de la lithiase rénale, une étude ethnobotanique a été réalisée, auprès de la population riveraine de la forêt d'Izarène.

Méthodes: A l'aide de 480 fiches questionnaires, des enquêtes ethnobotaniques sur le terrain ont été menées pendant trois campagnes (2013à 2016). La détermination des différents milieux d'enquêtes a été réalisée grâce aux techniques d'échantillonnage stratifié probabiliste. Les données ont été organisées et analysées par des statistiques descriptives. Les données ethnobotaniques ont été analysées via le calcul de différents indices quantitatifs, tels que : la 
Fréquence Relative de Citation (RFC), l'indice de valeur d'importance pour la famille (FIV) et la valeur d'usage de la partie de la plante (PPV).

Résultats: Les résultats ont montré 53 espèces végétales utiles, appartenant à 24 familles botaniques, qui ont été signalées dans le traitement de la lithiase rénale. La famille des Lamiaceae était la plus représentée $(10$ espèces, $F I V=0.043)$. La Fréquence Relative de Citation (RFC) la plus élevée $(0,173)$ a été enregistrée pour Herniaria hirsutas. Les résultats obtenus ont montré aussi que les feuilles sont la partie la plus utilisée $(P P V=0.216)$. La décoction est le mode de préparation dominant et l'administration se fait majoritairement par voie orale.

Conclusions: Les résultats obtenus pourraient constituer une base de données dans la perspective des expériences phytochimique, pharmacologique et de mise en œuvre des initiatives innovantes pouvant déboucher dans l'avenir sur la fabrication des médicaments traditionnels utilisables dans le traitement de la lithiase rénale.

Mots clés: Plantes médicinales, forêt d'Izarène, enquêtes ethnobotaniques, lithiase rénale.

\section{Background}

Urolithiasis is a frequent and recurrent disease, known since ancient times and is inseparable from the history of humanity (El Lekhlifi et al. 2014). It is a widespread condition that affects 4 to $20 \%$ of the population depending on the country (Doré B. 2004), with a recurrence rate of around $50 \%$ over five years (Docti 2013).

In Morocco, it is the second most common cause of hospitalization in urology after prostate adenoma; it is characterized by the formation of crystalline concretions developing in the pelvis and / or the calyces of a kidney causing a total or partial obstruction of normal flow of urine. Calculations have heterogeneous composition in 90 to $95 \%$ of cases. Thus, and for reasons of simplification, several publications limit the expression of crystal composition to the majority species (Daudon, 2005).Thus, there are four main types of lithiasis: calcium, uric acid, cystine and phosphate.

In Morocco, fragmentary epidemiological studies have shown that the nature of kidney stones is close to those of industrialized countries with a dominance of calcium oxalate followed by uric acid (Laziri et al. 2010; Boumzaoued et al. 2015; Bouatia et al. 2015). The formation of urinary calculi involves several factors such as sex, dietary intake, genetics, climatic aspects and metabolic disturbances (Badalato et al. 2011; Wasserstein 2011).
Today, despite the development of chemical drugs to control urinary diseases, the use of plants is often seen as a source of active substances. In addition, a significant portion of the population, especially in rural areas, prefers medicinal plants for economic reasons and sometimes because of difficulty in accessing medical care.

Morocco occupies a privileged place among the Mediterranean countries which have a long medical tradition and a traditional know-how containing medicinal plants (Scherrer et al. 2005). The richness of its traditional medicine has been demonstrated by several studies carried out in the field, which is a legacy of the Arab-Berber civilization and benefited largely from Muslim and Jewish tradition which reigned in this country (Jouad et al. 2003).

To document and thus perpetuate the traditional knowledge acquired by the local population, our laboratory tries to undertake floristic, ecological and ethnobotanic research of the medicinal plants on various parts of Morocco. Thus, diverse works were published on the Moroccan ethnobotanic knowledge among which we will cite: El Yahyaoui et al.2015; Orch et al.2015; El Azzouzi et al. 2015; Orch et al.2017; Chaachouay et al. 2019).

In this context, we carried out an ethnobotanical study which aims to identify and inventory the medicinal plants used for the treatment of urolithiasis among the population bordering the forest of Izarène known for its floristic and ecological diversity, and which offers to the local population a knowledge rather rich in traditional phytotherapy.

\section{Materials and Methods \\ Description of the study area}

The forest massif of Izarène is part of the TangierTétouan-Al Hoceïma area.It is located in the Northwestern zone of the Kingdom, $12 \mathrm{~km}$ to the NorthEast of the town of Ouezzane and covers an approximate forest surface of 14600 ha between the parallels $34^{\circ} 45^{\prime}$ and $34^{\circ} 58^{\prime} \mathrm{N}$ and the meridian lines $5^{\circ} 25^{\prime}$ and $5^{\circ} 32^{\prime} \mathrm{W}$. Limited to the southern part by marls of the Cretaceous pre-rifaine nappe, this forest massif is characterized by an uneven relief where the altitudes vary approximately between 350 and $680 \mathrm{~m}$ (HCEFLCD 2005).

The zone of study, the Circle of Mokrisset, is a part of the province of Ouezzane and group 3 Caïdats (Zoumi, Mokrisset and Brikcha), and 3 rural districts (Zoumi, AinBaïda and Brikcha) (Figure 1); it contains a population estimated at 25000 inhabitants (SPEF 2004). 


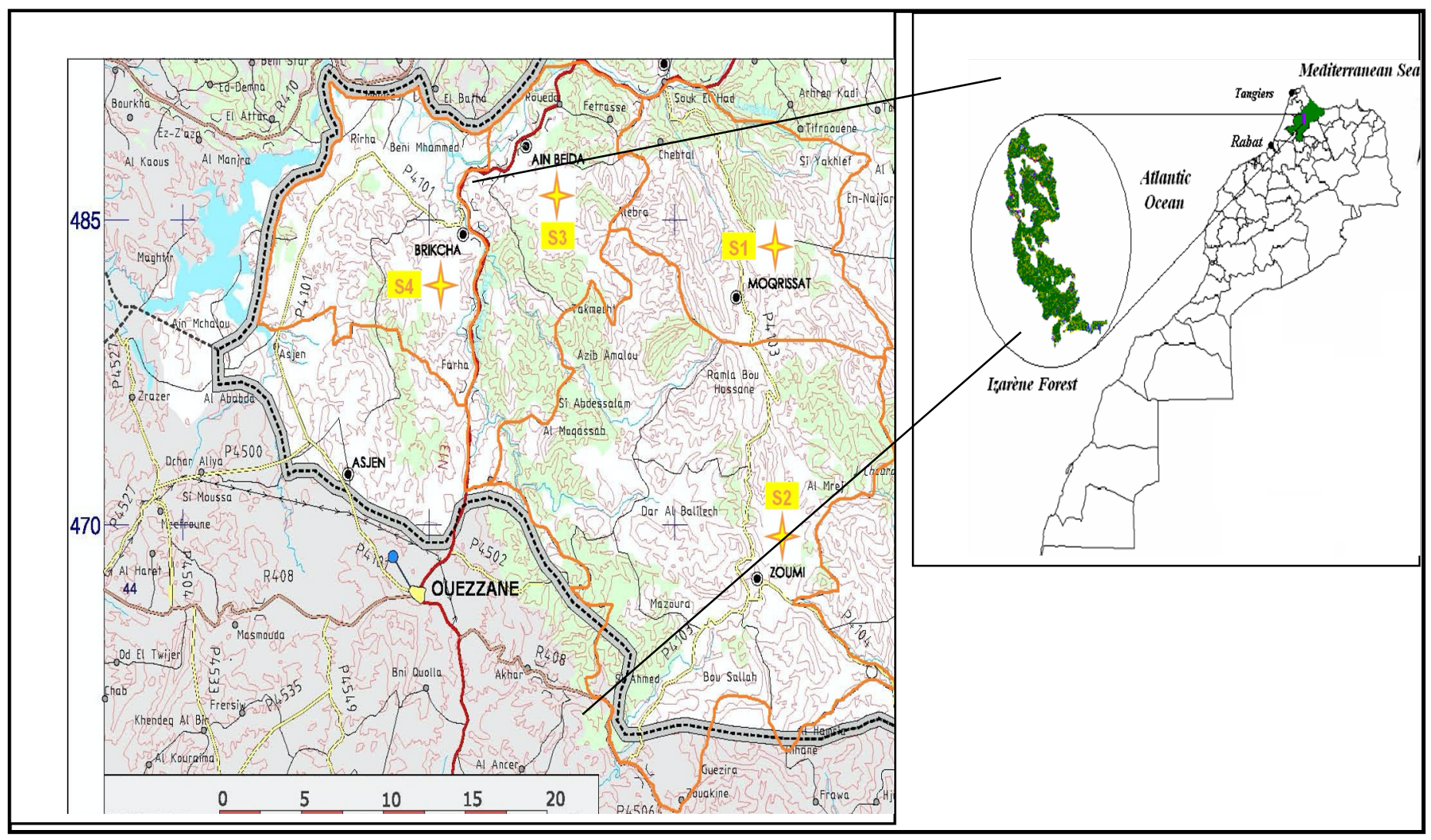

Figure 1. Location map of the study area

The geological formation of the forest massif is characterized by a tormented mountainous area due to the presence of several hills forming the beginning of the mountains of the Rifaine chain of the south side. These hills are characterized by a deep argiloslaty or argilo-marly soil which can reach in some places more than 3 meters of depth. The climate of the zone is sub-humid at moderate winter, the annual average precipitation would be about $1000 \mathrm{~mm}$. These precipitations are distributed over approximately 70 days during all the year (November to April). A mild very rainy winter with almost no frost is followed by a dry and hot season lasting 3 to 4 months (Askarn 1982).

The vegetation cover is characterized by a rich and diversified forest formation, consisting mainly of vegetation that shows a degradation of the climatic formation of the cork oak (Borgniet et al. 2009). The forest of Izarène has a vital economic, ecological and social importance for the bordering population. It assures the needs of the population for the firewood and for wori and constitutes the principal source of fodder for the cattle (SPEF 2004). Beyond its paramount functions, it also plays a role in traditional medicine thanks to the use of the medicinal plants as means of subsistence among the bordering population.

\section{Data collection}

In order to gather information about the use of medicinal plants used for the treatment of kidney stones, ethnobotanical surveys were carried out in different localities, villages and douars, bordering the forest of Izarène, during a period from 2013 to 2015.

The determination of the various mediums of inquiries was achieved thanks to the techniques of probabilistic stratified sampling (Godron 1971 \& 1982).In this study, the sample is divided into 4 homogeneous strata (S1, S2, S3 and S4), of which 3 correspond to the numbers of the rural communes of the Circle of Mokrisset (Table 1).

Table 1. Distribution of the surveys by strata

\begin{tabular}{|c|c|c|}
\hline Strata & $\begin{array}{c}\text { Names of } \\
\text { strata }\end{array}$ & $\begin{array}{c}\text { Number of } \\
\text { inquiries }\end{array}$ \\
\hline Strata 1 & Mokrisset & 120 \\
\hline Strata 2 & Zoumi & 120 \\
\hline Strata 3 & Ain Baïda & 120 \\
\hline Strata 4 & Brikcha & 120 \\
\hline \multicolumn{3}{|c|}{ Echantillon480 } \\
\hline
\end{tabular}

The investigation was carried out on 480 inhabitants of villages and douars of the studied zone. By adopting a random stratified sampling, samples of 120 people are then formed for each of the 4 strata 
and they are put together to constitute the total sample (480 people).

The field studies required us to deal with two groups: those who knew and/or used plants for medicinal goals and those who used plants and products for commercial purposes (plant collectors, herbalists, traditional practitioners The interviews with the informants were conducted in the Arabic dialect of the region. A questionnaire was prepared from the preliminary surveys in the study area and validated by a team from the botanical laboratory of the Faculty of Sciences of Kenitra. The questionnaire used consisted of two parts: The first part dealt with the demographic characteristics of the informants and the second focused on the plants used in the treatment of diseases (Appendix 1). The time devoted to each interview was approximately two hours, and the oral and written consent of the informants was collected for each interview. All persons who shared their traditional knowledge were informed about the principle of the study, its interest, and the procedure used while respecting the anonymity of the information collected.

Identification and conservation of plant species The taxonomic identification of the samples collected in the field was carried out, thanks to the following documents: The medicinal plants of Morocco of Sijelmassi (1993); Practical flora of Morocco of Fennane et al. (1999) and Catalogs of Vascular Plants of Northern Morocco, including identification keys, Valdés et al. (2002), Volumes I and II.

The botanical and ethnobotanical characteristics as well as the local name of the plants were noted on the samples deposited in the Laboratory of Biodiversity and Natural Resources, Department of Biology, Faculty of Sciences, Kenitra.

\section{Data Analysis}

The data recorded on the survey sheets were then transcribed into a database and processed by SPSS version 21 and the Excel spreadsheet (version 2010). Descriptive statistical methods were used to analyze the socio-demographic data of informants. To determine the socio-demographic parameters influencing the orientation of the riverside population towards traditional medication, an analytical study using logistic regression was conducted. Analysis of ethnobotanical data was carried out using the Relative Frequency of Citation (RFC), the Family Importance Value (FIV) and the Plant Part Value (PPV).

Relative frequency of citation (RFC)

$\mathrm{RFC}$ is calculated to appreciate the local importance of each species. The RFC is the result of the citation frequency ( $F c)$, that is the number of informants who mentioned the use of the species, divided by the total number $(\mathrm{N})$ of respondents (Tardio \& Pardo-deSantayana, 2008), with $(0<$ RFC $<1)$.

$\mathrm{RFC}=\mathrm{Fc} / \mathrm{N}$

\section{Family Importance Value (FIV)}

The Family Importance Value (FIV) identifies the importance of medicinal plant families. It is calculated using the method proposed by CadenaGonzález et al.(2013).

$\mathrm{FIV}=\mathrm{FC}$ familly $/ \mathrm{Ns}$;

where $\mathrm{FC}_{\text {familly: }} \mathrm{RFC}$ is the number of informants mentioning the family and Ns: total number of species in each family. Family use value is a culturally significant index that can be applied to ethnobotany to calculate the biological value of the plant taxon (Gakuubi \& Wanzala 2012).

\section{Plant Part Value (PPV)}

The PPV is calculated to appreciate the importance of each used part of the plant by the respondents, it is obtained by the following formula:

$P P V=R U_{\text {plant part }} / \mathrm{RU}$;

with $R U_{\text {plant part }}=$ is the sum of reported uses per part of the plant and $\mathrm{RU}=$ the number of reported uses of all parts of the plant.

\section{Results and Discussion}

Sociodemographic profile of the respondents This ethnobotanical study was carried out in a sample of 480 people, the results obtained show that the female predominates with 360 women (75\%), compared with 120 men (25\%) (Table 2), which corresponds to the sex ratio of 3 .

The predominance of women can be justified by the fact that women are always looking for natural herbal remedies, to improve their knowledge of these plants and to maintain their health as well as those of their families, since they are closer to the plants either in the medication of their children or in use in cooking. These results confirm the results of other ethnobotanical work carried out at the national level (Ziyyat_et al. 1997; Hmamouchi 2001; Jouad_et al. 2001;Eddouks_et al. 2002; Tahraoui_et al. 2007; Mehdioui_\&Kahouadji 2007; Salhi_et al. 2010; Benkhnigue_et al. 2010).

The use of medicinal plants concerns all age groups at the scale of the riparian population of the forest massif of Izarène. Our results show a predominance of the elderly, so those with an age over 60 represent $36.5 \%$. The age groups of [50-59], [40-49], [30-39], 
[18-29] have a percentage of $16.7 \%, 17.9 \%, 15 \%$ and $14 \%$, respectively. Indeed, older persons are expected to provide more reliable information on the traditional use of medicinal plants, because they hold much of the ancestral knowledge that is transmitted orally. The transmission of this knowledge is currently in danger because it is not always ensured (Weniger 1991; Anyinam 1995). The relative transmission of traditional practices from one generation to the next may explain the mistrust of some people, particularly young people, who tend not to believe too much in this traditional medicine. Concerning the level of education of the respondents in the study area, the results obtained show that the majority of users are illiterate with a percentage of $48.8 \%$, This relatively high percentage is directly correlated with the education level of the local population. Nevertheless, people with primary and secondary education have a significant percentage ( $27 \%$ and $17 \%$ respectively), while those with a university level have a percentage of $8 \%$. Other studies have shown that people's knowledge about the use of medicinal plants is held by illiterate people (Lahsissene et al. 2009; Omer et al. 2012).

Table 2. Socio-demographic characteristics of the participants in the study area.

\begin{tabular}{|c|c|c|c|}
\hline & Distribution & $\begin{array}{c}\text { Number of } \\
\text { informants }\end{array}$ & Percentages (\%) \\
\hline Gender & Male & 120 & 25.0 \\
& Female & 360 & 75.0 \\
\hline Age groups & {$[18-30[$} & 67 & 14.0 \\
& {$[30-40[$} & 72 & 15.0 \\
& {$[40-50[$} & 86 & 17.9 \\
& {$[50-60[$} & 96 & 20.0 \\
& $>60$ & 159 & 33.1 \\
\hline Educational level & Illiterate & 234 & 48.8 \\
& Primary & 128 & 26.7 \\
& Secondary & 81 & 16.9 \\
& University & 37 & 7.7 \\
\hline Family situation & Married & 407 & 84.8 \\
& Single & 73 & 15.2 \\
\hline Monthly income & Withoutincome & 204 & 42.5 \\
& Lowincome & 217 & 45.2 \\
& Averageincome & 59 & 12.3 \\
\hline
\end{tabular}

The residents surveyed in this region are mostly married with a percentage of $85 \%$ against $15 \%$ for single people.

Concerning the socio-economic level, $45.2 \%$ of respondents have a low socio-economic level, $42.5 \%$ are unemployed and $12.3 \%$ have an average level. The high level of poverty, the high cost of modern medical treatments and their side effects are the essential factors that push the local population to make extensive use of herbal medicine as reported in El Hassani's work in Middle Moulouya (El Hassani et al. 2013).

According to the logistic regression model, it appears that the variables: gender, age, and least expensive use are predictors influencing the orientation of the riverside population towards traditional medication, pointing out that the least expensive use factor represents an influence of 12 times more than the other factors (Table 3 ). The high cost of modern medical treatments, their side effects and the unfavorable socio-economic conditions of our population, are the essential factors that push the local population to make extensive use of herbal medicine. These results confirm the results achieved by El Hassani in Middle Moulouya (El Hassaniet al. 2013).

\section{Floristic analysis}

Botanical families most represented in the study area

Ethnobotanical field surveys have identified 53 species belonging to 24 families and divided into 50 genera. These plants are presented in alphabetical order in Table 4. For each plant listed, we give the scientific name, the family, the local name, the part used, the preparation method adopted by the local population, as well as the CF, RFC and FIV data.

The number of species and the FIV index revealed 6 families with high values of importance and which, as a result, are predominant in the treatment of urolithiasis (Figure 2). These are Lamiaceae (10 species with FIV=0.043), Apiaceae (6 species with $\mathrm{FIV}=0.042)$, Asteraceae (4 species with FIV= 
0.017), Brassicaceae (3 species with FIV $=0.024)$, Fabaceae ( 3 species with FIV $=0.075)$, Poaceae $(3$ species with $\mathrm{FIV}=0.072)$. The other remaining families have only one or two species. Indeed, these results have been confirmed by similar studies carried out in the Tan-Tan region of Morocco (Ghourri et al. 2013), and those carried out in the city of Oran in Algeria (Khitri et al. 2016).

\section{Relative Frequency of Citation}

Some species are more recommended by the local population than others; this results in a high citation frequency (CF). We calculated the citation frequency (RFC) as numerical representatives in the quantitative ethnobotanical survey to highlight the importance of traditional knowledge. Species with a very significant relative frequency of citation are those with a high level of use.

Among these plants, seven species belonging to seven botanical families are frequently used by the riparian population in the treatment of renal lithiasis. These are: Herniaria hirsutas(RFC=0.173), Ziziphus lotus (RFC=0.166), Zea mays (RFC=0.154), Petroselinum sativum (RFC=0.127), Glycyrrhiza glabra (RFC=0.125), Opuntia ficus-indica $(\mathrm{RFC}=0.116)$ and Crocus sativus (RFC $=0.10)$. This representativeness has also been observed, with some differences, in similar ethno-medicinal surveys conducted in other regions of Morocco (Hseini et al. 2007; Lahsissene et al. 2009; Ghourri et al. 2013; Khouchlaa et al. 2017).

Table 3. Statistical analyses of the influence of socio-demographic parameters on confidence in plant use.

\begin{tabular}{|l|c|c|c|c|}
\cline { 2 - 4 } \multicolumn{1}{c|}{} & \multirow{2}{*}{ Odds-Ratio } & \multicolumn{2}{c|}{ IC for 95\% } & \multirow{2}{*}{ p-value } \\
\cline { 3 - 4 } \multicolumn{1}{c|}{} & & Inferior & Superior & \\
\hline Gender & 0.189 & 0.08 & 0.445 & 0.000 \\
Age groups & 0.294 & 0.208 & 0.415 & 0.000 \\
Educational level & 1.147 & 0.893 & 1.474 & 0.282 \\
Family situation & 1.203 & 0.340 & 4.254 & 0.774 \\
Monthly income & 1.018 & 0.572 & 1.709 & 1.812 \\
least expensive use & 12.403 & 5.915 & 26.009 & 0.000 \\
\hline
\end{tabular}

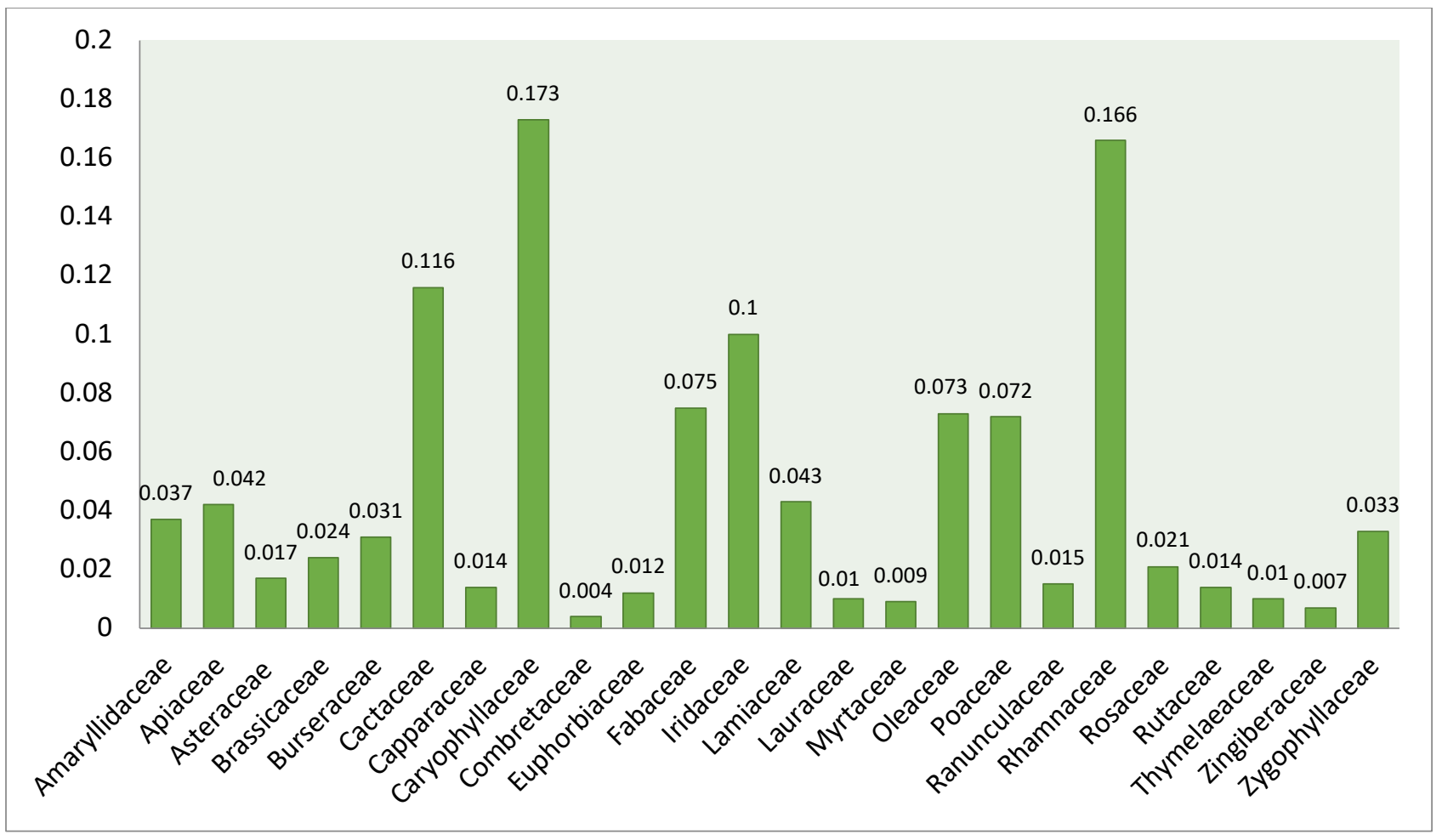

Figure 2. Distribution of medicinal plants according to the family importance value (FIV) in the study area. 
Table 4. List of medicinal plants used for the treatment of renal lithiasis in the study area.

\begin{tabular}{|c|c|c|c|c|c|c|c|}
\hline Family & Scientific name & Local name & $\begin{array}{l}\text { Parts } \\
\text { used }\end{array}$ & $\begin{array}{c}\text { Preparation } \\
\text { mode }\end{array}$ & Fc & RFC & FIV \\
\hline \multirow{2}{*}{ Amaryllidaceae } & Allium cepaL. & Lbesla & Other part & Raw & 30 & 0.062 & \multirow{2}{*}{0.037} \\
\hline & Allium sativumL. & Toum & Other part & Raw & 6 & 0.012 & \\
\hline \multirow{6}{*}{ Apiaceae } & $\begin{array}{l}\text { Ammi visnaga (L.) } \\
\text { Lam. }\end{array}$ & Bachnikha & Seeds & Decoction & 26 & 0.054 & \multirow{6}{*}{0.042} \\
\hline & Apium graveolens $\mathrm{L}$. & Krafèss & $\begin{array}{l}\text { Aerial } \\
\text { parts }\end{array}$ & Decoction & 2 & 0.0041 & \\
\hline & Daucus carota L. & Khizzu & Seeds & Decoction & 12 & 0.025 & \\
\hline & $\begin{array}{l}\text { Foeniculum vulgare } \\
\text { Gaertn. }\end{array}$ & Nafaâ & Seeds & Infusion & 13 & 0.027 & \\
\hline & $\begin{array}{l}\text { Petroselinum sativum } \\
\text { Hoffm. }\end{array}$ & Maâdanous & $\begin{array}{l}\text { Aerial } \\
\text { parts }\end{array}$ & Decoction & 61 & 0.127 & \\
\hline & Pimpinella anisum L. & Habbethlawa & Seeds & Decoction & 9 & 0.0187 & \\
\hline \multirow{4}{*}{$\begin{array}{l}\text { Asteraceae } \\
\text { (Composées) }\end{array}$} & $\begin{array}{l}\text { Artemisia herba alba } \\
\text { Assac. }\end{array}$ & Chih & Leaves & Infusion & 8 & 0.0166 & \multirow{4}{*}{0.017} \\
\hline & Inula viscosa (L.) Ait. & Terrahlâ & Leaves & Decoction & 12 & 0.025 & \\
\hline & Echinops spinosus L. & Tassekra & Roots & Decoction & 10 & 0.02 & \\
\hline & $\begin{array}{l}\text { Matricaria chamomilla } \\
\text { L. }\end{array}$ & Mansaniya & Flowers & Infusion & 3 & 0.006 & \\
\hline \multirow{3}{*}{$\begin{array}{l}\text { Brassicaceae } \\
\text { (Cruciferae) }\end{array}$} & $\begin{array}{l}\text { Anastatica } \\
\text { hierochuntica L. }\end{array}$ & âkarbâ & $\begin{array}{l}\text { Aerial } \\
\text { parts }\end{array}$ & Decoction & 12 & 0.025 & \multirow{3}{*}{0.024} \\
\hline & Brassica oleracea L. & Krumb & Leaves & Infusion & 8 & 0.0166 & \\
\hline & Lepidium sativum $\mathrm{L}$. & HabRchad & Seeds & Decoction & 15 & 0.031 & \\
\hline \multirow{2}{*}{ Burseraceae } & $\begin{array}{l}\text { Boswellia carterii } \\
\text { Birdw. }\end{array}$ & Salabân & Other part & Infusion & 20 & 0.041 & \multirow{2}{*}{0.031} \\
\hline & $\begin{array}{l}\text { Commiphora africana } \\
\text { (A. Rich) Engl. }\end{array}$ & Oumm-en-nâs & Other part & $\begin{array}{l}\text { Infusion, } \\
\text { powder }\end{array}$ & 11 & 0.022 & \\
\hline Cactaceae & $\begin{array}{l}\text { Opuntia ficus-indica } \\
\text { (L.) Mill. }\end{array}$ & $\begin{array}{l}\text { Nouwaratlhandi } \\
\text { ya }\end{array}$ & Flowers & Infusion & 56 & 0.116 & 0.116 \\
\hline Capparaceae & Capparis spinosa L. & Al'Kabbar & Fruits & Decoction & 7 & 0.014 & 0.014 \\
\hline Caryophyllaceae & Herniaria hirsuta L. & Herrastlahjar & $\begin{array}{l}\text { Whole } \\
\text { plant }\end{array}$ & Decoction & 83 & 0.173 & 0.173 \\
\hline Combretaceae & $\begin{array}{l}\text { Terminalia chebula } \\
\text { Retz. }\end{array}$ & Hlilije & Fruits & Powder & 2 & 0.004 & 0.004 \\
\hline Euphorbiaceae & Euphorbia falcata L. & $\begin{array}{l}\text { Hayyat en- } \\
\text { nufûs }\end{array}$ & $\begin{array}{l}\text { Whole } \\
\text { plant }\end{array}$ & Decoction & 6 & 0.012 & 0.012 \\
\hline \multirow{3}{*}{ Fabaceae } & Glycyrrhiza glabra L. & ârqsûss & Roots & Decoction & 60 & 0.125 & \multirow{3}{*}{0.075} \\
\hline & Medicago sativa L. & Fessa & Seeds & $\begin{array}{l}\text { Powder, } \\
\text { decoction }\end{array}$ & 45 & 0.093 & \\
\hline & Senna alexandrina Mill. & Sannâharam & Leaves & Infusion & 4 & 0.0083 & \\
\hline Iridaceae & Crocus sativus L. & Za'âfranelhor & Flowers & Decoction & 48 & 0.1 & 0.1 \\
\hline \multirow{9}{*}{ Lamiaceae } & Ajuga iva (L.) Schreb. & Chendgûra & $\begin{array}{l}\text { Aerial } \\
\text { parts }\end{array}$ & Powder & 31 & 0.064 & \multirow{9}{*}{0.043} \\
\hline & Lavandula dentata L. & Lakhzama & Flowers & $\begin{array}{l}\text { Decoction, } \\
\text { infusion, } \\
\text { powder }\end{array}$ & 15 & 0.0312 & \\
\hline & Lavandula multifida L. & Kohayla & Leaves & Decoction & 37 & 0.077 & \\
\hline & Marrubium vulgare L. & Merriwta & Leaves & Infusion & 12 & 0.025 & \\
\hline & Mentha rotundifolia L. & Mchichtrô & Leaves & Infusion & 9 & 0.0187 & \\
\hline & $\begin{array}{l}\text { Origanum compactum } \\
\text { Bentham. }\end{array}$ & Zaâtar & Leaves & Infusion & 27 & 0.056 & \\
\hline & Origanum majorana L. & Merdedouch & Leaves & Infusion & 29 & 0.06 & \\
\hline & $\begin{array}{l}\text { Rosmarinus officinalis } \\
\text { L. }\end{array}$ & Aazir & Leaves & Decoction & 14 & 0.03 & \\
\hline & Salvia officinalis L. & Assalmiya & Leaves & Decoction & 18 & 0.0375 & \\
\hline
\end{tabular}




\begin{tabular}{|c|c|c|c|c|c|c|c|}
\hline & Thymus vulgaris $\mathrm{L}$. & Zaîtra & $\begin{array}{l}\text { Aerial } \\
\text { parts }\end{array}$ & Decoction & 13 & 0.027 & \\
\hline Lauraceae & $\begin{array}{l}\text { Cinnamomum } \\
\text { zaylanicum Nees. }\end{array}$ & Qorfa & Other part & Powder & 5 & 0.01 & 0.01 \\
\hline \multirow[b]{2}{*}{ Myrtaceae } & $\begin{array}{l}\text { Eucalyptus globulus } \\
\text { Labill. }\end{array}$ & Al' Kalitûs & Leaves & Decoction & 8 & 0.016 & \multirow[b]{2}{*}{0.009} \\
\hline & $\begin{array}{l}\text { Eugenia caryophyllata } \\
\text { Thunb }\end{array}$ & Qronfel & Flowers & $\begin{array}{l}\text { Decoction, } \\
\text { powder, and } \\
\text { maceration }\end{array}$ & 1 & 0.002 & \\
\hline Oleaceae & $\begin{array}{l}\text { Olea europaea var. } \\
\text { sativa }\end{array}$ & Zitoun, Zabbouj & Leaves & $\begin{array}{l}\text { Decoction, } \\
\text { infusion }\end{array}$ & 35 & 0.073 & 0.073 \\
\hline \multirow{3}{*}{ Poaceae } & $\begin{array}{l}\text { Cynodon dactylon L. } \\
\text { Pers. }\end{array}$ & Njem & Roots & Decoction & 11 & 0.023 & \multirow{3}{*}{0.072} \\
\hline & Hordeum vulgare L. & Chaâir & Seeds & Decoction & 20 & 0.041 & \\
\hline & Zea mays L. & LahyatAdra & Flowers & Decoction & 74 & 0.154 & \\
\hline \multirow[b]{2}{*}{ Ranunculaceae } & Nigella sativa L. & Assânûj & Seeds & Decoction & 12 & 0.025 & \multirow[b]{2}{*}{0.015} \\
\hline & $\begin{array}{l}\text { Ranunculus muricatus } \\
\text { L. }\end{array}$ & Wdene l'halûf & Roots & Powder & 3 & 0.006 & \\
\hline Rhamnaceae & Ziziphus lotus (L.) Lam. & Nbeg & Fruits & Decoction & 80 & 0.166 & 0.166 \\
\hline \multirow{2}{*}{ Rosaceae } & Cydonia oblonga Mill. & Ssferjel & Leaves & Decoction & 6 & 0.0125 & \multirow{2}{*}{0.021} \\
\hline & Prunus domestica L. & Barkuk & Fruits & Infusion & 14 & 0.03 & \\
\hline Rutaceae & Citrus limon (L.) Brum. & Lhâmmed & Fruits & Other & 7 & 0.014 & 0.014 \\
\hline Thymelaeaceae & $\begin{array}{l}\text { Thymelaea lythroides } \\
\text { L. }\end{array}$ & L'metnâne & Leaves & Decoction & 5 & 0.010 & 0.010 \\
\hline \multirow[b]{2}{*}{ Zingiberaceae } & $\begin{array}{l}\text { Alpinia officinarum } \\
\text { Han. }\end{array}$ & khdenjâl & Other part & Powder & 2 & 0.004 & \multirow[b]{2}{*}{0,007} \\
\hline & Zingiber officinal Rosc. & Sekinjbîr & Other part & $\begin{array}{l}\text { Decoction, } \\
\text { powder, and } \\
\text { maceration }\end{array}$ & 5 & 0.01 & \\
\hline Zygophyllaceae & $\begin{array}{l}\text { Zygophyllum gaetulum } \\
\text { Emb. \& Maire }\end{array}$ & Al'âggaya & $\begin{array}{l}\text { Aerial } \\
\text { parts }\end{array}$ & Infusion & 16 & 0.033 & 0.033 \\
\hline
\end{tabular}

In addition, some of the identified plants are recognized by their toxic potential, such as Nigella sativa (Zaoui et al. 2000; Bnouham et al. 2002), Zygophyllum gaetulum and Artemisia herba-alba (Eddouks et al. 2002; Tahraoui et al. 2007). Indeed, the majority of the herbalists are unaware of the toxicity of the plants used as well as the methods of their use, in particular the methods of preparation and the recommended doses. The use of medicinal plants must be rationalized and the benefit/risk determined. Studies on these objectives are therefore necessary.

Frequency of Use of the Medicinal Plants According to their Origin

The ethnobotanical study identified 53 antilithiasic medicinal plants. Among them, 28 species are imported from other parts of the country, while 17 species are cultivated and 8 species collected from the forest of Izarène. Among these last species, four medicinal plants, Mentha rotundifolia, Origanum compactum, Ajuga iva and Euphorbia falcata are scarce in the region and may disappear from the forest if no protective measures are taken by the services concerned, due to the intensive collection of these species.

\section{Ethnobotanical analysis Parts used}

To prepare therapeutic recipes used in the treatment of urolithiasis, various parts of the listed plants are exploited by the local population (leaves, flowers, fruit, seed...). The calculation of the PPV use index revealed that the leaves are the most used parts with a PPV index $=0.216$, followed by flowers with a $P P V=0.185$ index, then the seeds (PPV $=0.142$ ). The other parts are used to a lesser degree (Figure 3 ). Indeed, these results have been confirmed by similar ethnobotanical studies carried out in other regions of Morocco (Ghourri et al. 2013; ElYahyaoui et al. 2015; Sbai-Jouilil et al. 2017). The leaves are the most used because they are at the same time central to the photochemical reactions and reservoirs of organic matter derived from them, and therefore rich in active ingredients, and because they are parts that are easy to collect.

\section{Method of preparation and administration}

In order to administer the active ingredients contained in medicinal plants, the population bordering the forest of Izarène uses several methods of preparation for the treatment of renal lithiasis (decoction, infusion, powder, raw...). Decoction is the most commonly used method of administration with 
a percentage of $50 \%$ (Figure 4), followed by Infusion preparation with a percentage of $25.8 \%$ and the use of powdered plant with a percentage of $16.2 \%$, the other methods of preparation, namely the use of raw plant, maceration and others, represent $8 \%$. The high percentage of the decoction preparation shows that the local population believes in this type of preparation and finds it adequate to warm the body and disinfect the plant to cancel the toxic effect of some recipes, but decoction can destroy some active ingredients of the species used.

In the study area, the oral route is the most widely used for most plants. However, the majority of respondents do not know the weights, dose, and precise measures to be prescribed in the preparation and dosage of herbal medicines.

\section{Origin of information on medicinal plants}

Concerning the therapeutic use of medicinal plants, the majority of respondents collected information through the experience of people around them $(62.8 \%)$, which reflects the image of the relative transmission of traditional practices from one generation to the next. Herbalists are ranked as the second most important source of information $(20.6 \%)$ and a small minority $(16.6 \%)$ through their own experience via television programs

\section{Conclusions}

Renal lithiasis is a genuine public health problem. The use of medicinal plants for therapeutic purposes has received renewed attention and interest throughout Morocco and in developing countries in general.

The level of poverty and the high cost of treatment provided by modern medicine, in addition to annoying side effects, are the main factors that drive the population bordering the forest of Izarène to use the medicinal plants of the traditional pharmacopoeia in the treatment of renal lithiasis.

The study carried out in the region of Izarène, showed the potential richness of the medicinal flora used in the treatment of urolithiasis diseases. Indeed, 53 medicinal species have been identified among the actors of traditional medicine in the study area; they belong to 24 families and are divided into 53 genera. Depending on the number of species and the FIV index, the most represented families are Lamiaceae, Apiaceae and Asteraceae.

Decoction is the most common method of use, while leaves are the plant's most commonly used plant organs in phytotherapeutic treatment, and the study identified threatened species.

This work is a source of information that contributes to a knowledge of the medicinal flora and a safeguard of local popular knowledge. It can also constitute a database for phytochemists and pharmacologists for the valorization of medicinal plants used in urinary lithiasis diseases in order to discover new active ingredients that can be used in pharmacology.

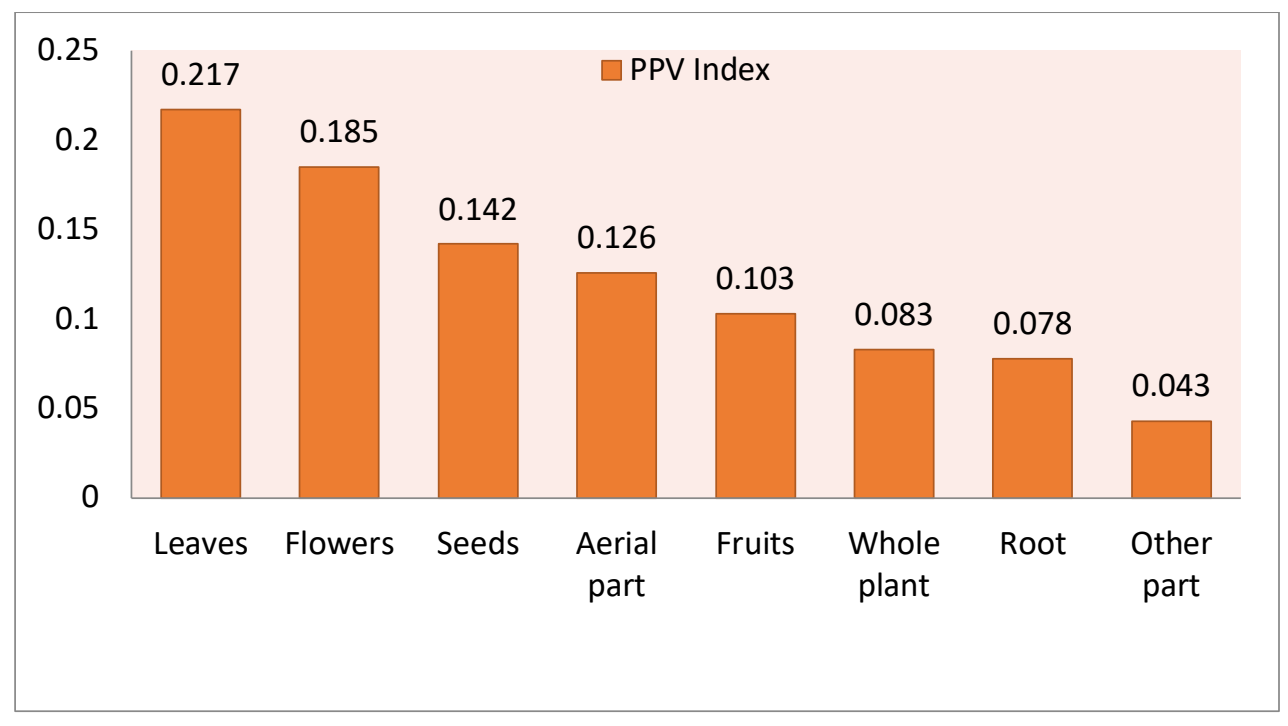

Figure 3. Percentages of Different parts used for the treatment of renal lithiasis diseases in the zone of study. 


\section{Frequency \%}

3.23 .21 .6
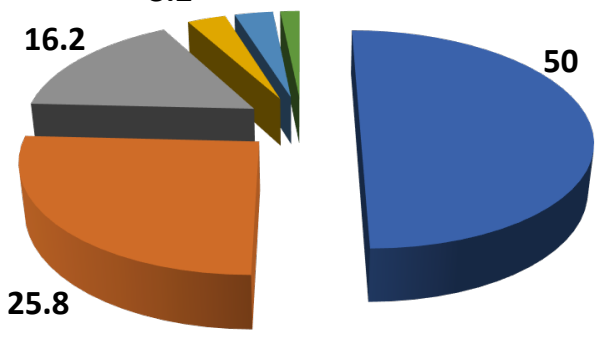

Decoction

Infusion

Powder

Maceration

Raw

Other

Figure 4. Percentages of different modes of remedies preparation used in the zone of study.

\section{Declarations}

List of Abbreviations: SPSS: statistical package for social science, $\mathbf{F}_{\mathrm{c}}$ : frequency of citation RFC: relative frequency of citation, FIV: family importance value, PPV: plant part value

Ethics approval and consent to participate: Before conducting interviews, all participants gave their prior consent knowing the reason for the study. Authors contributions: $\mathrm{HO}$ : Compiled the literature sources, data analysis, and interpretation and wrote the manuscript. OB: Helped in data, LZ, MF and AD: supervised the work and improved the manuscript. All authors read, reviewed and approved the final version of the manuscript.

Consent for publication: Not applicable

Availability of data and materials: The data was not deposited in public repositories.

Funding: This research did not receive funding.

Conflicts of interest: The authors declare that there is no conflict of interests regarding the publication of this paper.

\section{Literature Cited}

Anyinam C. 1995. Ecology and ethnomedicine: exploring links between current environmental crisis and indigenous medical practices. Social Science and Medicine, 4:321-329.

Askarn O. 1982. Comportement des Résineux dans l'Arboretum d'Izarène. Mémoire de Troisième Cycle Agronomie, Institut Agronomique et Vétérinaire Hassan II, Rabat, Maroc, 122 p.

Badalato G M, Santos Cortes J, Gupta M. 2011. Treatment of Upper Urinary Lithiasis in patients who have undergone urinary diversion. Current Urology Review 12(2):121-125.

Benkhnigue O, Zidane L, Fadli M, Elyacoubi $\mathrm{H}$, Rochdi A, Douira A. 2010. Etude ethnobotanique des plantes médicinales dans la région de Mechraa Bel Ksiri (Région du Gharb du Maroc). Barc 53:191-216.
Bnouham M, Mekhfi H, Legssyer A, Ziyyat A. 2002. Medicinal plants used in the treatment of diabetes in Morocco. International Journal of Diabetes and Metabolism 10: 33-50.

Borgniet L, Long M, Capel A C, Bouillon C, Morge D, Ganteaume A, Lampin C, Jappiot M, Curt T, Machrouh A, Sesbou A, Mantzavelas A, Apostolopoulou I, Partozis T, Gitas I, Marell A, Cassagne N, Pimont F, Rigolot E, Morsdorf F, Koetz $B$ and Allgower B. 2009. Development of an easy to use tool to recognize and map fuel models. Deliverable D5.1-6 of the Integrated Project "Fire Paradox", Project no. FP6-018505. European Commission. 112 p.

Bouatia M, Benramdane L, Oulad Bouyahya Idrissi $M$ and Draoui M. 2015. An epidemiological study on the composition of urinary stones in Morocco in relation to age and sex. African Journal of Urology 21:194-7.

Boumzaoued H, Laziri F, El Lekhlifi Z, Qarro A et El Assyry A. 2015. Prevalence of urinary lithiasis in the Moulay Ismail Military Hospital (Meknes-Morocco). Journal of Material and Environmental Science 6(6):1578-83.

Cadena-González, A L, Sørensen M, Theilade I. 2013. Use and valuation of nativeand introduced medicinal plant species in Campo Hermoso and Zetaquira,Boyacá, Colombia. Journal of Ethnobiology and Ethnomedicine 9:1-34.

Chaachouay N, Benkhnigue O, Fadli M, El Ayadi R, Zidane L. 2019. Ethnopharmacological studies of Medicinal and Aromatic Plants Used in the Treatment of Respiratory System Disorders in the Rif. Morocco. Ethnobotany Research \& Applications.18:22.

Daudon M, Hennequin C, Boujelben G, Lacour B et Jungers P. 2005. Serial crystalluria determination and the risk of recurrence in calcium stone formers. Kidney International. 67(5):1934-43. 
Docti news, no 51, Janvier 2013.

Doré B. Les lithiases rénales. Springer. Paris 2004, pp 49-77.

Eddouks M, Maghrani M, Lemhadri A, Ouahidi M L, Jouad H. 2002. Ethnopharmacological survey of medicinal plants used for the treatment of diabetes mellitus, hypertension and cardiac diseases in the south-east region of Morocco (Tafilalet). Journal of Ethnopharmacology 82:97-103.

El Azzouzi F, Zidane L. 2015. The traditional medicinal flora of the Beni-Mellal region (Morocco). Journal of Applied Biosciences.91(1):8493-8502.

El Hassani M, Douiri E M, Bammi J, Zidane L, Badoc A, Douira A. 2013. Plantes médicinales de la Moyenne Moulouya (Nord-Est du Maroc). Ethnopharmacologia. 50.

El Lekhlifi Z, Laziri F, Boumzaoued H, Maouloua M and Louktibi M. 2014. Étude épidémiologique rétrospective sur la lithiase urinaire chez l'enfant la région de Meknès au Maroc (2000-2012). Journal de Pédiatrie et de Puériculture 27(1):23-28.

El Yahyaoui O, Ait ouaaziz N, Sammama A, Kerrouri, Bouabid B, Lrhorfi L A, Zidane $L$ et Bengueddour R. Étude ethnobotanique des plantes médicinales commercialisées à la province de Laâyoune : identification et utilisation. 2015. International Journal of Innovation and Applied Studies 12:53341.

Fennane M, Ibn Tattou M, Mathez J, Ouyahya A, El Oualidi J. 1999. Flore pratique du Maroc. Vol. I. 558 p. Rabat.

Gakuubi M M, Wanzala W. 2012. A survey of plants and plant products traditionally used in livestock health management in Buuri district, MeruCounty, Kenya. Journal of Ethnobiology and Ethnomedicine 8. 1-19.

Ghourri M, Zidane L, Douira A. 2013. Usage des plantes médicinales dans le traitement du Diabète Au Sahara marocain (Tan -Tan). Journal of Animal \&Plant Sciences 17(1):2388-2411.

Godron M. 1971. Essai sur une approche probabiliste de l'écologie des végétations. Thèse Doct. D'Etat, U.S.T.L. Montpellier. 247p.

Godron M, Daget Ph. 1982. Analyse de l'écologie des espèces dans les communautés Coll. Ecol. 18. Masson. 163p.

HCEFLCD. 2005. Haut Commissariat des Eaux et Forêts et de la lutte contre la désertification. Incendie de forêt au Maroc, situation actuelle et perspective d'avenir. $10 \mathrm{p}$.

Hmamouchi M. 2001. Les plantes médicinales et aromatiques marocaines. 2éme. Ed. 389 p.

Hseini S, Kahouadji A. 2007. Etude ethnobotanique de la flore médicinale dans la région de Rabat (Maroc occidental). Lazaroa 28:79-93.
Jouad H, Haloui M, Rhiouani H, El-Hilaly J, Eddouks M. 2001. Ethnobotanical survey of medicinal plants used for the treatment of diabetes, cardiac and renal diseases in the North centre region of Morocco (FezBoulemane). Journal of Ethnopharmacology 77:175182.

Jouad H, Maghrani M, El Hassani R A, Eddouks M. 2003. Hypoglycemic activity of aqueous extract of Eucalyptus globulus in normal and streptozotocininduced diabetic rats. Journal of Herbs. Spices and Medicinal Plants 10:19-28.

Khitri W, Lachgueur N, Tasfaout A, Lardjam A et Khalfa A. 2016. Plantes antilithiasiques utilisées en medicine traditionnelle dans la ville d'Oran, Algérie. Approche ethnobotanique et phytochimique. Revue d'ethnoécologie. doi:10.4000/ethnoecologie2511.

Khouchlaa A. Etude ethnopharmacologique, essais biochimiques de Zizyphus lotus L. sur la dissolution de deux types de calculs rénaux et identification des molécules actives. Faculté des Sciences. Université Mohammed V, Rabat. Thèse de doctorat, 2017.

Lahsissene H, Kahouadji A, Tijane M, Hseini S. 2009. Catalogue des plantes médicinales utilisées dans la région de Zaër (Maroc occidental). Lejeunia 186:1-26.

Laziri $F$, RhaziFilali $F$, Oussama A, Soulaymani A, Qarro A, Lezrak M. 2010. Facteurs impliqués dans l'épidémiologie des calculs urinaires marocains. Journal Maroc Urologie 19:9-14.

Mehdioui R. et Kahouadji A. 2007. Etude ethnobotanique auprès de la population riveraine de la forêt d'Amsittène: cas de la Commune d'Imi n'Tlit (Province d'Essaouira). Bulletin de l'Institut Scientifique, Rabat, section Sciences de la Vie 29:11-20.

Omer SA, Elobeid MA, Elamin MH, Hassan ZK, Virk $\mathrm{P}$, Daghestani $\mathrm{MH}$, Al-Olayan, EM, Al-Eisa NA et Almarhoon ZM. 2012. Toxicity of olive leaves (Olea europaea L.) in wistar albino rats. Asian Journal of Animal Veterinary Advances 7:1175-82.

Orch H, Zidane L, Douira A. 2015. Étude ethnobotanique des plantes médicinales utilisées dans le traitement du diabète, et des maladies cardiaques dans la région d'lzarène (Nord du Maroc). Journal of Applied Biosciences 86:79407956.

Orch H, Zidane L, Douira A. 2017. Ethnobotanical study of the plants used in the treatment of the digestive diseases by the riverine population of the forest of izarène. International Journal of Recent Scientific Research. Vol. 8. Issue, 1, pp. 1521315220.

Salhi S, Fadli M, Zidane L, Douira A. 2010. Etudes floristique et ethnobotaniques des plantes médicinales de la ville de Kénitra (Maroc). Lazaroa 31:133-146. 
Sbai-Jouilil, Anas Fadli A, El HafianM, El Ayad R, Benharbit O, Zidane L. 2017. Floristic and Ethnobotanical Study of Medicinal Plants Used in the Treatment of Respiratory Diseases in Seksaoua Region (Western High Moroccan Atlas). Annual Research \& Review in Biology. 17(6): 1-10. ARRB. 36526.

Scherrer A M, Motti R, Weckerle C S. 2005. Traditional plant use in the areas of Monte Vesole and Ascea, Cilento National Park (Campania, Southern Italy). Journal of Ethnopharmacology 97 : 129-143.

Sijelmassi A. 1993. Les plantes médicinales du Maroc, 6ème édition. Fennec. 285 p. Casablanca.

SPEF. 2004. Incendie du massif forestier d'Izarène du 23 au 25 août 2004. Service Provincial des Eaux et Forêts de Chefchaouen. 17p.

Tahraoui A, El-Hilaly J, Israili Z H, Lyoussi B. 2007. Ethnopharmacological survey of plants used in the traditionaltreatment of hypertension and diabetes in south-eastern Morocco (Errachidia province). Journal of Ethnopharmacology 110. 105-117.

Tardío J, Pardo-de-Santayana M. 2008. Cultural importance indices: a comparative analysis based on the useful wild plants of Southern Cantabria (Northern Spain). Economic Botany. 62 (1) : 24-39.

Valdés B, Rejdali M, Achhal El Kadmiri A, Jury JL, Montserrat M. 2002. Catalogues des plantes vasculaires du Nord du Maroc, incluant des clés d'identification. 2 Volumes. 1498 p. Madrid.

Wasserstein A G. 2011. Epidemiology and natural history of nephrolithiasis. Clinical Reviews in Bone and Mineral Metabolism 9 (3): 165-180. [doi: 10.1007/s12018-011-9097-3].

Weniger B. 1991. Interest and limitation of a global ethnopharmacological survey.Journal of Ethnopharmacology 32, 37-41.

Zaoui A, Cherrah Y, Lacaille-Dubois MA, Settaf A, Amarouch H, Hassar M. 2000. Diuretic and hypotensive effects of Nigella sativa on the spontaneously hypertensive rat. Therapie 55, 379382.

Ziyyat A, Legssyer A, Mekhfi H, Dassouli A, Serhrouchni M, Benjelloun W. 1997. Phytotherapy of hypertension and diabetes in oriental Morocco. Journal of Ethnopharmacology 58, 45/54. 
Appendix 1. Questionnaire sheets: Medicinal plants and phytotherapy.

\begin{tabular}{|c|c|}
\hline Date... & Commune... \\
\hline 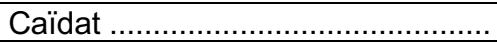 & Survey number.............................. \\
\hline
\end{tabular}

\begin{tabular}{|c|c|c|c|c|c|}
\hline Age & $\begin{array}{c}\text { Mokrisset } \\
\text { (S1) }\end{array}$ & Zoumi (S2) & Ain Baïda (S3) & Brikcha (S4) & Total \\
\hline \multicolumn{6}{|l|}{ [18-30[ } \\
\hline \multicolumn{6}{|l|}{ [30-40[ } \\
\hline \multicolumn{6}{|l|}{ [40-50[ } \\
\hline \multicolumn{6}{|l|}{ [50-60[ } \\
\hline \multicolumn{6}{|l|}{$>60$} \\
\hline Job & $\begin{array}{c}\text { Mokrisset } \\
\text { (S1) }\end{array}$ & Zoumi (S2) & Ain Baïda (S3) & Brikcha (S4) & Total \\
\hline Sex & $\begin{array}{c}\text { Mokrisset } \\
\text { (S1) }\end{array}$ & Zoumi (S2) & Ain Baïda (S3) & Brikcha (S4) & Total \\
\hline \multicolumn{6}{|l|}{ Male } \\
\hline \multicolumn{6}{|l|}{ Female } \\
\hline Family situation & $\begin{array}{l}\text { Mokrisset } \\
\text { (S1) }\end{array}$ & Zoumi (S2) & Ain Baïda (S3) & Brikcha (S4) & Total \\
\hline \multicolumn{6}{|l|}{ Single } \\
\hline \multicolumn{6}{|l|}{ Married } \\
\hline Level of study & $\begin{array}{l}\text { Mokrisset } \\
\text { (S1) }\end{array}$ & Zoumi (S2) & Ain Baïda (S3) & Brikcha (S4) & Total \\
\hline \multicolumn{6}{|l|}{ Illiterate } \\
\hline \multicolumn{6}{|l|}{ Primary } \\
\hline \multicolumn{6}{|l|}{ Secondary } \\
\hline \multicolumn{6}{|l|}{ University } \\
\hline Locality & $\begin{array}{c}\text { Mokrisset } \\
\text { (S1) }\end{array}$ & Zoumi (S2) & Ain Baïda (S3) & Brikcha (S4) & Total \\
\hline \multicolumn{6}{|l|}{ Village } \\
\hline \multicolumn{6}{|l|}{ Douar } \\
\hline $\begin{array}{l}\text { Income / month } \\
\text { (MAD) }\end{array}$ & $\begin{array}{l}\text { Mokrisset } \\
\text { (S1) }\end{array}$ & Zoumi (S2) & Ain Baïda (S3) & Brikcha (S4) & Total \\
\hline \multicolumn{6}{|l|}{ No income } \\
\hline \multicolumn{6}{|l|}{ Low income } \\
\hline \multicolumn{6}{|l|}{ Average income } \\
\hline $\begin{array}{l}\text { When you feel sick, } \\
\text { you address: }\end{array}$ & $\begin{array}{c}\text { Mokrisset } \\
\text { (S1) }\end{array}$ & Zoumi (S2) & Ain Baïda (S3) & Brikcha (S4) & Total \\
\hline \multicolumn{6}{|l|}{ Traditional medicine } \\
\hline \multicolumn{6}{|l|}{ Modern medicine } \\
\hline \multicolumn{6}{|l|}{$\begin{array}{l}\text { Traditional medicine } \\
\text { and Modern medicine }\end{array}$} \\
\hline $\begin{array}{l}\text { To traditional } \\
\text { medicine, why? }\end{array}$ & $\begin{array}{l}\text { Mokrisset } \\
\text { (S1) }\end{array}$ & Zoumi (S2) & Ain Baïda (S3) & Brikcha (S4) & Total \\
\hline \multicolumn{6}{|l|}{ Effective } \\
\hline \multicolumn{6}{|l|}{ Cheapest } \\
\hline \multicolumn{6}{|l|}{ Acquisition } \\
\hline Ineffective medication & & & & & \\
\hline Plant Type & $\begin{array}{c}\text { Mokrisset } \\
\text { (S1) }\end{array}$ & Zoumi (S2) & Ain Baïda (S3) & Brikcha (S4) & Total \\
\hline Spontaneous & & & & & \\
\hline Cultivated & & & & & \\
\hline Introduced & & & & & \\
\hline Use of the plant & $\begin{array}{c}\text { Mokrisset } \\
\text { (S1) }\end{array}$ & Zoumi (S2) & Ain Baïda (S3) & Brikcha (S4) & Total \\
\hline Therapeutic & & & & & \\
\hline Cosmetic & & & & & \\
\hline Other & & & & & \\
\hline $\begin{array}{l}\text { Harvesting } \\
\text { technique }\end{array}$ & $\begin{array}{l}\text { Mokrisset } \\
\text { (S1) }\end{array}$ & Zoumi (S2) & Ain Baïda (S3) & Brikcha (S4) & Total \\
\hline Manual & & & & & \\
\hline Mechanical & & & & & \\
\hline
\end{tabular}


Appendix 1. Questionnaire sheets: Medicinal plants and phytotherapy. (continued...)

\begin{tabular}{|c|c|c|c|c|c|}
\hline Harvest Time & Mokrisset (S1) & Zoumi (S2) & $\begin{array}{l}\text { Ain Baïda } \\
\text { (S3) }\end{array}$ & Brikcha (S4) & Total \\
\hline \multicolumn{6}{|l|}{ Summer } \\
\hline \multicolumn{6}{|l|}{ Fall } \\
\hline \multicolumn{6}{|l|}{ Winter } \\
\hline \multicolumn{6}{|l|}{ Spring } \\
\hline \multicolumn{6}{|l|}{ Any year } \\
\hline $\begin{array}{l}\text { If desiccated, } \\
\text { drying method }\end{array}$ & Mokrisset (S1) & Zoumi (S2) & $\begin{array}{l}\text { Ain Baïda } \\
\text { (S3) }\end{array}$ & Brikcha (S4) & Total \\
\hline \multicolumn{6}{|l|}{ Sun exposure } \\
\hline \multicolumn{6}{|l|}{ In the Shade } \\
\hline Use of the plant & Mokrisset (S1) & Zoumi (S2) & $\begin{array}{l}\text { Ain Baïda } \\
\text { (S3) }\end{array}$ & Brikcha (S4) & Total \\
\hline \multicolumn{6}{|l|}{ Fresh } \\
\hline \multicolumn{6}{|l|}{ Desiccated } \\
\hline \multicolumn{6}{|l|}{ After treatment } \\
\hline Used part & Mokrisset (S1) & Zoumi (S2) & $\begin{array}{c}\text { Ain Baïda } \\
\text { (S3) }\end{array}$ & Brikcha (S4) & Total \\
\hline \multicolumn{6}{|l|}{ Fruit } \\
\hline \multicolumn{6}{|l|}{ Stem } \\
\hline \multicolumn{6}{|l|}{ Whole plant } \\
\hline \multicolumn{6}{|l|}{ Seed } \\
\hline \multicolumn{6}{|l|}{ Rhizome } \\
\hline \multicolumn{6}{|l|}{ Other combination } \\
\hline \multicolumn{6}{|l|}{ Root } \\
\hline \multicolumn{6}{|l|}{ Bark } \\
\hline \multicolumn{6}{|l|}{ Leaf } \\
\hline \multicolumn{6}{|l|}{ Flower } \\
\hline \multicolumn{6}{|l|}{ Bulb } \\
\hline $\begin{array}{l}\text { Form of } \\
\text { employment }\end{array}$ & Mokrisset (S1) & Zoumi (S2) & $\begin{array}{l}\text { Ain Baïda } \\
\text { (S3) }\end{array}$ & Brikcha (S4) & Total \\
\hline Tisane & & & & & \\
\hline Powder & & & & & \\
\hline Essential oil & & & & & \\
\hline Oily oil & & & & & \\
\hline Tincture & & & & & \\
\hline $\begin{array}{l}\text { Method of } \\
\text { preparation }\end{array}$ & Mokrisset (S1) & Zoumi (S2) & $\begin{array}{l}\text { Ain Baïda } \\
\text { (S3) }\end{array}$ & Brikcha (S4) & Total \\
\hline Decoction & & & & & \\
\hline Infusion & & & & & \\
\hline Cataplasm & & & & & \\
\hline Raw & & & & & \\
\hline Cooked & & & & & \\
\hline Powder & & & & & \\
\hline Maceration & & & & & \\
\hline Others & & & & & \\
\hline Dose used & Mokrisset (S1) & Zoumi (S2) & $\begin{array}{l}\text { Ain Baïda } \\
\text { (S3) }\end{array}$ & Brikcha (S4) & Total \\
\hline Pinch & & & & & \\
\hline Handle & & & & & \\
\hline Spoonful & & & & & \\
\hline $\begin{array}{l}\text { Administration } \\
\text { mode }\end{array}$ & Mokrisset (S1) & Zoumi (S2) & $\begin{array}{l}\text { Ain Baïda } \\
\text { (S3) }\end{array}$ & Brikcha (S4) & Total \\
\hline Oral & & & & & \\
\hline Massage & & & & & \\
\hline Rinse & & & & & \\
\hline Brushing & & & & & \\
\hline Inhalation & & & & & \\
\hline Others & & & & & \\
\hline
\end{tabular}




\begin{tabular}{|c|c|c|c|c|c|}
\hline Dosage for children & Mokrisset (S1) & Zoumi (S2) & $\begin{array}{c}\text { Ain Baïda } \\
\text { (S3) }\end{array}$ & Brikcha (S4) & Total \\
\hline \multicolumn{6}{|l|}{ 1time/day } \\
\hline \multicolumn{6}{|l|}{ 2time/day } \\
\hline \multicolumn{6}{|l|}{ 3time/day } \\
\hline \multicolumn{6}{|l|}{ Other } \\
\hline Dosage for adults & Mokrisset (S1) & Zoumi (S2) & $\begin{array}{l}\text { Ain Baïda } \\
\text { (S3) }\end{array}$ & Brikcha (S4) & Total \\
\hline \multicolumn{6}{|l|}{ 1time/day } \\
\hline \multicolumn{6}{|l|}{ 2time/day } \\
\hline \multicolumn{6}{|l|}{ 3time/day } \\
\hline \multicolumn{6}{|l|}{ Other } \\
\hline $\begin{array}{l}\text { Dosage for older } \\
\text { people }\end{array}$ & Mokrisset (S1) & Zoumi (S2) & $\begin{array}{c}\text { Ain Baïda } \\
\text { (S3) }\end{array}$ & Brikcha (S4) & Total \\
\hline \multicolumn{6}{|l|}{ 1time/day } \\
\hline \multicolumn{6}{|l|}{ 2time/day } \\
\hline \multicolumn{6}{|l|}{ 3time/day } \\
\hline \multicolumn{6}{|l|}{ Other } \\
\hline Length of Use & Mokrisset (S1) & Zoumi (S2) & $\begin{array}{l}\text { Ain Baïda } \\
\text { (S3) }\end{array}$ & Brikcha (S4) & Total \\
\hline \multicolumn{6}{|l|}{ One day } \\
\hline \multicolumn{6}{|l|}{ A week } \\
\hline \multicolumn{6}{|l|}{ One month } \\
\hline \multicolumn{6}{|l|}{ Until healing } \\
\hline $\begin{array}{l}\text { Conservation } \\
\text { method }\end{array}$ & Mokrisset (S1) & Zoumi (S2) & $\begin{array}{l}\text { Ain Baïda } \\
\text { (S3) }\end{array}$ & Brikcha (S4) & Total \\
\hline \multicolumn{6}{|l|}{$\begin{array}{l}\text { Sheltered from the } \\
\text { light }\end{array}$} \\
\hline \multicolumn{6}{|l|}{ Exposed to light } \\
\hline \multicolumn{6}{|l|}{ Other } \\
\hline Diagnosis By & Mokrisset (S1) & Zoumi (S2) & $\begin{array}{c}\text { Ain Baïda } \\
\text { (S3) }\end{array}$ & Brikcha (S4) & Total \\
\hline \multicolumn{6}{|l|}{ Himself } \\
\hline \multicolumn{6}{|l|}{ Doctor } \\
\hline \multicolumn{6}{|l|}{ Herbalist } \\
\hline \multicolumn{6}{|l|}{ Other } \\
\hline Results & Mokrisset (S1) & Zoumi (S2) & $\begin{array}{c}\text { Ain Baïda } \\
\text { (S3) }\end{array}$ & Brikcha (S4) & Total \\
\hline \multicolumn{6}{|l|}{ Healing } \\
\hline \multicolumn{6}{|l|}{ Improvement } \\
\hline \multicolumn{6}{|l|}{ Ineffective } \\
\hline Side effects & Mokrisset (S1) & Zoumi (S2) & $\begin{array}{c}\text { Ain Baïda } \\
\text { (S3) }\end{array}$ & Brikcha (S4) & Total \\
\hline \multicolumn{6}{|l|}{ No } \\
\hline Yes & & & & & \\
\hline Toxicity & Mokrisset (S1) & Zoumi (S2) & $\begin{array}{c}\text { Ain Baïda } \\
\text { (S3) }\end{array}$ & Brikcha (S4) & Total \\
\hline No & & & & & \\
\hline Yes & & & & & \\
\hline
\end{tabular}

